\title{
Peculiarities and development factors of modern agricultural engineering
}

\author{
Tatyana Zhukova ${ }^{1, *}$, Olga Panfilova ${ }^{1}$, Ilona Avlasenko ${ }^{1}$, and Lyudmila Avlasenko ${ }^{1}$ \\ ${ }^{1}$ Don State Technical University, 1, Gagarin Square, 344003, Rostov-on-Don, Russia
}

\begin{abstract}
Functioning dynamics of agricultural engineering nowadays is under analysis in this article. It is noted that the formation of a modern agricultural cluster is influenced by many factors that can cause problems for its optimal functioning. The topical question is to define the role of state regulation of the agricultural machinery industry in Russia, to search for the new regulating economic instruments for the effectively developing agro-industrial complex. Adaptation of agricultural engineering to a constantly changing competitive market and the ability of domestic producers to survive in a crisis depends on the favorable conditions created for the agricultural producer and on the use of the support mechanisms that are adequate to the current state of the market.
\end{abstract}

\section{Introduction}

The development of agricultural engineering remains one of the leading and most essential lines of industrial development in Russia. Agricultural giants contribute significantly to the formation of gross domestic product, forming a stable sector of the economy, that is the basis for the formation of a competitive economy. Orientation to the resource economy definitely acts as an obstacle for the economic growth, that is focused on the effective paths of development. In such environment the formation of basic leading clusters becomes an objective of high priority, which helps us to go to the new stage of optimization of all types of resources, including elements of a digital innovative economy. The main strategic goal is the creation of a competitive, stable, structurally balanced economy in Russian Federation [1].

Constant attention is given to the study of modern agricultural engineering as one of the basic areas that determines the agricultural production vector. These problems are considered in the articles of the following authors: Polukhin A.A., Alekseev K.I., Aganbegyan A.G., Terentyeva O.N., Goldin I.I., Mishchenko K.N., Sredshchikova I.V., etc.

The authors assess the current economic and foreign policy situation, analyze the need for import substitution in the agricultural machinery market as the most important factor to ensure the country's food security. Significant attention is also paid to the prospects for technical and technological modernization of agriculture in Russia in accordance with the necessity to implement the state program for the development of agriculture.

\footnotetext{
${ }^{*}$ Corresponding author: tzhukova.work@yandex.ru
} 
It is noted that the material and technical base as the basis for the functioning of production, its basic component, is one of the main conditions that determines the production of products of the Russian agribusiness sectors [2].

However, the constant transformation of economic relations, the search of the new forms of interrelations against the backdrop of deepening processes of economic integration and globalization, the optimization of state regulation and the growth of economic responsibility degree of each business entity leads to the necessity to analyze the existing vector of economic strategy, identify the causes and factors that impede the process of entering the Russian economy into the system of world economic relations.

Agricultural engineering is one of the prospective areas of the modern economy; its success depends on variety of actors: on the stability of the national economy as a whole, the course of the state and strategic social and economic development, on external world influences. In recent years, there has been a positive trend in the production and demand for the product of Russian agricultural machinery.

\section{Materials and Methods}

The object of the research is the agricultural engineering industry in a state of transformation of market relations and international economic integration. Such vector of analysis helps to search for the conditions that affect the efficiency of the enterprises of the agricultural sector.

Resistance to crisis phenomena in the national and international economies is precisely ensured due to the use of benefits available to the agricultural producer, that have being realized until recently through state support.

Methods of quantitative and qualitative analysis are used in this paper, they are implemented by studying the role of agricultural engineering in the national economy and identifying the main trends in their development. The study of the priority processes of the Russian economy in terms of increased competition, determining the place of the agricultural sector in the framework of the economic development strategy serves as an element of qualitative analysis. The analysis of statistical material reflecting the main macroeconomic indicators allows us to determine the role of the agricultural machinebuilding industry, its contribution to national achievements.

Direct quantitative research is based on the analysis of statistical material that characterizes the role and place of agro-industrial complex in Russian economy. Data on the dynamics of the performance of agricultural engineering indicate unstable processes in this area, which is associated both with the characteristics of the national economy and with global economic fluctuations and external factors.

A qualitative analysis reflects the dynamics of agricultural regulatory mechanisms, the search of new ways to improve it in accordance with the selected priorities of the country's economic development. In this regard, the transition to new methods of state regulation of the agricultural machinery production sector, the activation of innovative trends adequate to the current state of the market is being investigated.

Theoretical and methodological approaches are used in this article to study the specifics of the functioning of agricultural engineering in conditions of transforming market relations and changing indicative mechanisms within the chosen strategy. Analytical studies are used to find out the reasons of the phenomenon under the study. Statistical analysis serves as the basis of the probative base. 


\section{Results}

The growth of the agricultural engineering industry is correlated with the ensuring food security in Russia. Achievement of the parameters identified in the Program of socioeconomic development of the country is connected with a decreasing dependence on many processes in global economy, ensuring the stable development of the agro-industrial sector of the economy, with the demand for many industries, and also with a significant reduction in dependence on imports of machinery, equipment, technologies and other resources.

The main indicators of the modern strategy of economic development are oriented towards the increasing competitiveness of domestic industry and its leading branches.

The presence of the multiplier effect of the agricultural machine-building sector development is associated with the demand for the products of many industries related to this field (chemical, metallurgical, instrument-making, machine-tool building, etc.). This ensures the stability of the economy as a whole and the possibility of integration of an interregional nature, forming clusters of a stable type [3].

Speaking about the effectiveness of agricultural production, the positive dynamics in recent years should be noted. The volume of agricultural machinery production in Russia in 2016 amounted to about 88 billion rubles, which is a significant increase compared to 2015 . Changes in the economy allowed agricultural equipment manufacturers to ensure solvent demand, and at the same time providing a stable position in the market. It also allowed to narrow the significant competitive gap between Russian and foreign manufacturers in this industry. Agricultural machinery exports in 2016 amounted to 7.7 billion rubles, which again indicates a positive trend in this market [4].

In recent years, agricultural machinery was exported to almost 47 countries, mainly EEC countries, they account for almost $70 \%$ of exports.

The significant tax effect of the dynamically developing sector of agricultural engineering should be noted, it provides a significant amount of deductions of agricultural engineering enterprises to the country's budget. Thus, tax deductions to the state budget and extrabudgetary state funds in 2016 amounted to more than 30 billion rubles.

However, there is a number of factors that destabilize this process.

Despite the significant progress in the development of agricultural engineering due to the state support and a significant share of the labor force employed in this industry, a low investment activity in this area as a negative impact factor should also be noted. This restricts the ability of agricultural engineering enterprises to realize the growth of their potential and the development of the multiplier effect of the development.

The investment process and the development of the research sphere for the development of agricultural machinery, however, takes place, although it reflects insufficient growth. The share of investments in research and development has grown almost 7 times since 2014; the number of employed designers increased by $15 \%$ [5].

Considering current trends in the development of the agricultural sector, a number of factors contributing to the positive dynamics in this area can be noted, among them:

- the presence of Russian basic components in the production of agricultural machinery, an insignificant level of application of foreign components and materials;

- the presence of its own production base able to provide the domestic demand for agricultural machinery products; provision with agricultural machinery of the agroindustrial sector in Russia;

- high capital-labor ratio of agricultural production by Russian combines and other equipment. Until recently, state subsidies played a substantial role, they actually provided free supply of these means of production to Russian fields; 
- the competitiveness of Russian agricultural engineering products. First of all, we are talking about the agricultural machinery giant Rostselmash, whose agricultural machines harvest more than $80 \%$ of the country's crop;

- the potential for intensification of agricultural production through the investment growth, which contributes to the growth of industry sustainability through the development and expansion of markets;

- State support for the agricultural machinery exports, which contributes to the restructuring of enterprises aimed at the production of high-quality equipment, which is also in demand on foreign markets [6].

However, one should not forget about the competitive global market, for example, in the USA and in France no less productive combines are used. Their production capacity allows them to process over 60 hectares per season. However, there are some features of the use of agricultural machinery. The average tractor load in the USA does not exceed 40 hectares, and in Russia it is more than 300 hectares. These figures reflect trends in constant demand for agricultural machinery products of a sufficiently high quality and productivity [7].

As you know, the dynamics of the global economy is determined by many processes, including the movement of the global financial system. Therefore, when determining export flows in the agricultural engineering market, the dynamics of the global financial market should be taken into account. Also the contribution of the leading world countries to provide the aggregate global demand for agricultural machinery should be predicted considering the trends in this direction. When determining the indicators of the export plan, the cost of this process and the possible effect of such actions should be taken into account [8].

The dynamics of agricultural engineering reflects the demand and quality of the machinery for farmers. In 2016 the market for grain harvesting equipment went up by $37 \%$. About 6 thousand Rostselmash combines were sold and the number of high-power machines prevailed. The requirements of agricultural producers are constantly growing, taking into account market opportunities. Therefore, the main task of agricultural producers is to maintain and increase their position in the competitive market, considering the peculiarities of Russian agribusiness and the financial capabilities of the region.

Among the factors that expand the possibilities of increasing production is the presence of a complete production cycle, from the design of machines to their after-sales service. Such cycle exists in LLC "KZ"Rostselmash" and includes foundry, welding, paintwork and assembly work. Holding's agricultural machines are delivered to the world leading countries, allowing to realize the significant volumes of the processed crop.

Negative factors in the development of the industry include:

- focus mainly on the domestic market and a low share of exports. Russian combines, despite the competition in this market, are certainly a sought-after product for foreign manufacturers. There is always a need for agricultural machinery. However, recent geopolitical processes have negatively affected the development of these relationships, reducing economic ties between enterprises in economic confrontation, in a state of sanctions

- low financial opportunities for manufacturers of agricultural machinery associated with the development, production and sale of products. Here, first of all, the state's decision to switch to new methods of regulating the sphere of agricultural engineering is causing alarm, thus Russian agricultural machinery is planned to be left without a key support measure in the form of subsidies;

- insufficient degree of activity of innovative measures and a low level of costs for research and development;

- lack of skilled labor to be integrated with the latest developments in engineering and technology. 
It is worth to mention the problem of subsidies. Since 2020 the government plans to abolish agricultural subsidies, when discounts to buyers of combines, tractors and of other products were provided. Due to preferential production conditions in accordance with the existing subsidy program, Russian agricultural producers significantly increased their export deliveries. In case of refusal of such a program, a significant drop in production is possible with high probability; there is an opinion that such a fall can be three times. As a result, the market share of agricultural machinery consumers can be reduced by more than 2 times, the reduction in the number of employees can reach $40 \%$, and the decrease in wages $-25 \%$.

In recent years, under the so-called 1432 Programme, the State has subsidized the producer part of the production costs, and the producer has sold equipment to farmers at a discount of 15-20 per cent. According to the President of "Novoe Sodruzhestvo" Konstantin Babkin, under this program almost all combine machines were sold in Russia. In 2019 the Russian government decided to replace the discount subsidy program with preferential leasing. The result was a lack of orders for agricultural machinery. Under such conditions "Rostselmash" will have to adjust to the new realities of the market, which, accordingly, can create a lot of problematic factors affecting the possibilities of production and sale of agricultural machinery.

The possible elimination of subsidies for agromachine producers from 2020, planned by the Government of the Russian Federation, will lead to the formation of expensive production, the increase in the cost of products and prices on the market, which will place an unsustainable burden on the agricultural producer. As an alternative, leasing mechanisms are proposed. However, this will require both time, improvement of the legislative framework and formation of conditions of economic interest of the participating parties.

Considering rather long period of subsidies established, the rejection of subsidies and their replacement by a leasing system will unlikely have any effective consequences. Russian producers and farmers have worked under this scheme for many years, and the transition to another platform of relations which involves financial difficulties above all will not have a positive effect for a long time. Taking into account the peculiarities of Russian economic development and the existing system of financial and credit regulation, this process can ensure high efficiency if there is a whole set of related changes of a systemic nature. In fact, there is a rather difficult scenario for the development of Russian agricultural production today. The share of agricultural equipment provided by leasing in recent years has been an order of magnitude lower than that acquired.

It should be taken into account that the sale of agricultural machinery through the leasing system over the next five years will require an additional 500 billion rubles.

The launch of new leasing schemes will take quite a long time both on the part of the government and agricultural producers, as well as on the part of leasing companies. It will also take time to refine this mechanism and bring it into a state adapted to the modern market. The mechanism of operation of such system is not clear yet to the manufacturer as it was not involved in the development of a potential mechanism for leasing agricultural machinery in modern conditions.

This decision, proposed in May 2019, will have a significant impact on the prospects of investment activity for the enterprise and on the possibilities of its participation in the investment policy of all agricultural engineering.

The process of overproduction started at the plant Rostselmash. More than a thousand unrealized harvesters has already been accumulated there, and this number increased while the production still continued to work in full mode. The consequence of such changes is certainly a revision of the production plan, a decrease in the production plan of agricultural machinery for next year. 
It is known that KZ LLC "Rostselmash" sent 10 thousand of its employees on forced leave in summer. In autumn some of Rostselmash 's employees were transferred to a threeday working week.

Before that the company went on vacation for two months, the plant was idle in August and September. Top management explained this fact by winding down the village support program.

As the top manager K. Babkin noted, there are still about 500 unsold harvesters left on Rostselmash, but it is not planned to postpone the resumption of production of machines for later terms.

The decline in the entrepreneurial activity of agricultural production will also affect related enterprises. As a result, a variety of industries will suffer: chemical, petrochemical, metallurgy, instrument-making, energy, etc. Undoubtedly, such a chain of negative integration process will affect the overall state of the country 's economic condition. And whether these actions will lead to an imbalance in the export-import ratio is one of the threats to the economic security of the country.

Many CIS countries successfully carry out trade relations with Russia including Minsk Tractor Plant, Gomselmash, as well as representatives of the distant foreign countries working under the brands "John Deere," CNH, "Claas," AGCO, "SDF." In addition, here it is important to allow the Russian producer to participate in the creation of a competitive product, this will lead to an increase in the share in the GDP of the country.

The state in its economic policy should be guided by the interests of national producers and pursue a course to reduce the dependence of the Russian agro-industrial complex on imports of means of production and technologies, in recent years this tendency has prevailed in Russian market of agricultural machinery [9].

The development of its own agricultural machinery will allow Russia to pursue an independent policy aimed at the import substitution of food, machinery and equipment to ensure the food security of the country. The release of Russian mechanical engineering from the leading industries of Russia and the continuing trend of replacing agricultural mechanical engineering products with imports means the rejection of the development of one of the most prospective directions of Russian production [10].

While assessing the role and prospects of the Russian agro-industrial sector the fundamental provisions of the strategic direction of the Russian economy should be taken into account:

- Agricultural machinery in Russia is the most important element of the agro-industrial sector;

- The agricultural machinery industry has competitive production competence in the development and production of equipment for the agro-industrial sector;

- The Russian market of agricultural machines is rather promising in general, this fact makes impractical gradual leveling and transferring of agricultural machinery to foreign producers;

- The national food security of the country depends to a large extent on the development of a heavy industry providing the country with food and means of production for permanent reproduction.

\section{Discussion}

Agricultural machinery in Russia is represented mainly by enterprises of large and mediumsized businesses, and in countries with developed agricultural machinery small businesses clearly predominate. This is a consequence of the transformation of economic systems in the historical period and the dependence on the basic conditions of economic development, as well as the dependence on the possibilities to develop socialization of production and 
capital. The implementation of the strategy for the development of agricultural engineering in Russia is directly related to the international integration of the country into the world economy. Threats and advantages of Russian agricultural engineering form conditions for the entrance of this industry into the world economy [11].

State regulation of agricultural production is carried out in accordance with the principles that ensure the creation of a competitive agro-industrial sector as a part of the entire national economy. Such principles include ensuring the food security of the country, programmatic and targeted regulation taking into account the formation of an effective agricultural cluster, reasonable agrarian protectionism, motivational orientation of state support measures to optimize agricultural production, a combination of various economic instruments.

Under these circumstances the importance of competitive policies implemented by economic entities and the transformation of competitive relations is increasing. All this forms the degree of social recognition of the product by consumers and the prospects for further development of the relationships of market actors. Such a strategic approach to solving problems at the level of microeconomic actors requires the formation of adequate policies based on managerial, financial and economic instruments that contribute to the growth of its overall socio-economic efficiency.

The technical basis of the agro-industrial sector is shown in the following figure. When considering data, it should be borne in mind that the economy of agricultural engineering is influenced by many factors, the underestimation of these factors leads to a decrease in the competitiveness of products and services. Primarily such factors as the availability of the resource base, its qualitative characteristics, the stock capacity of the production process, the availability of agricultural machinery should be mentioned. Demand for agricultural machinery products depends on many conditions, that are determined by the level of development of the country 's economy as a whole, and on the priorities of the state 's economic policy, which determines the degree of accessibility of agricultural machinery by farmers and other agricultural producers. The yield of production is the result of these most numerous endogenous and exogenous factors. Consequently, the solution to the problem is the result of a comprehensive analysis of the current situation in the agricultural engineering market [12].

The basic indicator of the activity assessment of agricultural producers is the availability of agricultural machinery to enterprises. This indicator has increased steadily in recent years.

However, in order to assess the real prospects for the development of agricultural machinery, it is necessary to take into account the qualitative characteristics of agricultural machinery, as well as the competitive environment in the market of technical means.

It is important to assess the competitiveness of the environment in the study of the agricultural market [13].

The method of structure evaluation of the material-and-technical base for the agribusiness plant and analysis of the competitive environment includes a number of stages:

- Analysis and evaluation of the type of competitive environment in the agricultural market;

- Analysis and evaluation of the competitive environment structure in the agricultural market. The main indicators for the market assessment are the sale of substitute goods, analysis of prices, profitability and elasticity of demand for agribusiness equipment, availability of information;

- Evaluation of the intensity of competition and development of recommendations on the formation of competitive environment in the market of agribusiness equipment. The main criteria of the market here are: the nature of distribution of market shares, the degree of intensity of competition in the market, the coefficient of relative concentration. Great 
importance is attached in this regard to the necessity and nature of state regulation of the processes of creating a competitive environment in this market.

Today the state of technical and economic indicators of the agricultural machinery market is significantly inferior to foreign ones. The gap is rather considerable. The mechanism to stimulate demand, subsidies for technical re-equipment of agricultural machinery production enterprises, elimination of subsidies to villagers, etc., does not allow to achieve the desired result in increasing the efficiency of this sector. The cluster of agricultural production simultaneously forms a set of shortcomings for effective integration into the system of a single national and world economy.

With the existing technical and technological level of agricultural development and agricultural machinery Russian enterprises, unfortunately, are unable to compete with foreign producers [14].

Therefore, the system of state support remains one of the pressing levers for the formation of competitive production. As the state measures to protect national producers some economists propose the following measures:

- Provision of affordable credit by the banking system, which has always been one of the appropriate measures during the crisis;

- Possibilities of refinancing the obligations of entrepreneurs to commercial banks;

- Search for new economic instruments to protect domestic producers.

The importance of domestic agricultural machinery for the Russian economy is undeniable, it can be shown clearly.

Table 1. Capacity of agricultural machinery market.

\begin{tabular}{|l|c|c|}
\hline \multicolumn{2}{|c|}{$\begin{array}{c}\text { Agricultural mechanical engineering. } \\
\text { Market capacity 141 billion rubles. }\end{array}$} \\
\hline Crop production & Production of food & $\begin{array}{c}\text { Sales of products of agricultural } \\
\text { mechanical engineering }\end{array}$ \\
\hline
\end{tabular}

The strategy of agricultural engineering development involves the creation of competitive agricultural machinery that meets modern requirements when used in industries based on innovation and implementation of $R \& D$ results. The investment process, which ensures this direction of the industry, will have a positive effect both for the agricultural engineering industry itself and for related sectors of the entire agricultural cluster.

The implementation of the set tasks will allow Russian agricultural engineering industry in 2020 to become a high-tech industry with modern enterprises producing agricultural equipment competitive on the world market, demanded by the agricultural producer in quantity, composition and quality sufficient to ensure national food security and increase export supplies.

The peculiarities of the development of Russian economy do not allow to predict for several decades ahead the conditions when the functioning of the production sector will be carried out. Instability of the financial sector, dependence on external factors, as well as the specificity of economic development make impossible to predict trends in the mechanism of transformation of the tax and monetary system, but foreign economic factors make constant adjustments to the operation system of economic mechanisms and instruments.

Thus, actual subsidies to producers and farmers have been the main support mechanism for the industry. Starting from 2020, the Government intends to switch to a preferential leasing mechanism.

A critical assessment of the transition to preferential leasing, according to a number of experts, is primarily related to the allocation mechanism itself, the insufficient development of a system of activities of such kind. The heads of the major flagships of agricultural engineering express doubts about the feasibility of such transition. As life has shown, so far the result of such changes in economic policy has been a change in the regime of operation 
of the plant "Rostselmash," problems in the labor market, and uncertainty of further optimization of labor resources in number of regions. The previous system of subsidies allowed to carry out and expand investments in this sphere, it also allowed to expand nomenclature and increase production of Russian agricultural machinery.

In recent years the government paid close attention to agricultural engineering. After all, this industry is fundamental for the development of a number of related industries. The considerable funds allocated by the Government from the federal budget to support this production allowed producers to maintain domestic demand for this product and to program its constant increase. For example, in 201715.7 billion rubles were allocated from the federal budget under the program of subsidizing agricultural machinery producers.

The decision to change the support mechanism entails major changes in a number of sectors of the agro-industrial cluster. The limited domestic market opportunities based on these schemes will force the manufacturer to find other ways of distribution, including export. The main driver of the development of Russian agricultural machinery industry will be foreign markets. The ratio of exports to imports of products of this industry will be changed significantly. The development strategy of Russian agricultural engineering for the period up to 2030 provides that the ratio of exports to products supplied to the domestic market by 2025 should reach $50 \%$. This ratio has been considerably lower during the previous years.

Russia's share in world exports of agricultural machinery in 2017 remained at point less than $1 \%$. The volume of supplies to foreign markets in the leading economies of the world is significantly higher.

According to the target indicators for the implementation of the development strategy for Russian agricultural engineering for the period up to 2030, by 2025 the ratio of exports to shipments of agricultural engineering products for the domestic market should be $50 \%$. In 2017 the figure under consideration was 12\%. As for the dynamics of supply of agricultural machines of Russian production abroad, in recent years there has been a steady increase in their value. According to the Ministry of Industry and Trade of the Russian Federation, in 2016 the export of agricultural machinery from Russia amounted to 6.8 billion rubles; In 2017 it went up to 7.9 billion rubles, and in 2018 - to 11 billion rubles, which corresponds to an increase of almost $40 \%$ to the level of the previous year.

The current state of the market of equipment manufacturers for the needs of agricultural enterprises, the level and mechanisms of existing state support, as well as the strategic indicators show good prospects in this industry. Further development of agricultural engineering within the framework of the adopted state strategies will make possible not only to saturate domestic needs through import substitution, but also to master export potential.

Table 2. Target indicators of export evaluation of agricultural machinery (share of exports in total production), $\%$.

\begin{tabular}{|c|l|l|l|l|}
\hline $\begin{array}{c}\text { Type of the } \\
\text { equipment }\end{array}$ & \multicolumn{2}{|c|}{ Actual data } & \multicolumn{2}{c|}{ Target indicator } \\
\hline & 2015 & 2016 & 2020 & 2025 \\
\hline Tractors & 6.4 & 7.1 & 10 & 25 \\
\hline Combine harvesters & 17.3 & 12.2 & 25 & 40 \\
\hline Forage harvesters & 24.8 & 17.5 & 25 & 40 \\
\hline
\end{tabular}

The final indicators of the industry and the success of all production and economic activities of enterprises fully depends on the logistics of agriculture. The current economic situation indicates the dynamic development of Russian agricultural engineering in a number of market segments. Constant analysis of indicators of realization and direction of export potential of domestic producers of agricultural machines will allow to identify 
reserves of development of agro-industrial sphere and more intensive development of the international market.

Table 3. Target indicators for the implementation of the Strategy for the Development of Agricultural Engineering of Russia for the Period up to 2030.

\begin{tabular}{|l|c|c|c|c|}
\hline \multicolumn{1}{|c|}{ Indicators } & $\mathbf{2 0 1 7}$ & $\begin{array}{c}\text { 1st } \\
\text { stage } \\
\mathbf{( 2 0 2 1 )}\end{array}$ & $\begin{array}{c}\text { 2nd stage } \\
\mathbf{( 2 0 2 5 )}\end{array}$ & $\begin{array}{c}\text { 3d stage } \\
\mathbf{( 2 0 3 0 )}\end{array}$ \\
\hline $\begin{array}{l}\text { Share of Russian agricultural machinery } \\
\text { products in the domestic market in the total } \\
\text { volume. \% }\end{array}$ & 56 & 80 & $\begin{array}{c}\text { Not lower } \\
80\end{array}$ & $\begin{array}{c}\text { Not lower } \\
80\end{array}$ \\
\hline $\begin{array}{l}\text { Ratio of exports and shipments of agricultural } \\
\text { machinery products to the domestic market. \% }\end{array}$ & 12 & 25 & 50 & $\begin{array}{c}\text { Not lower } \\
50\end{array}$ \\
\hline Index of agricultural machinery production. \% & 112 & 112 & 112 & 106 \\
\hline $\begin{array}{l}\text { Share of R\&D expenditures in total revenues of } \\
\text { agricultural machinery enterprises. \% }\end{array}$ & 0.7 & 1.5 & 3 & 3.2 \\
\hline $\begin{array}{l}\text { Number of designers employed in agricultural } \\
\text { machinery }\end{array}$ & 750 & 1000 & 1700 & 2100 \\
\hline $\begin{array}{l}\text { Share of foreign components and materials in } \\
\text { the total cost of produced agricultural } \\
\text { machinery products. \% }\end{array}$ & 35 & 20 & 15 & 10 \\
\hline
\end{tabular}

Target indicators of external orientation of agricultural engineering correspond to strategic criteria of export development. Therefore, the production of the necessary equipment of both domestic and foreign brands with high localization can be considered in part as a solution to the problem of forming an export-oriented direction. Moreover, the dynamics of this industry, the existing demand and the competitive advantages of Russian equipment in domestic and foreign markets show that the proposed targets are real and appropriate.

\section{Conclusions}

Consequently, within the framework of the export development strategy of Russian agricultural machinery, the main task remains the same - meeting the demand of the domestic market, constantly increasing as it is expected. The program of development of agricultural engineering provides that by 2025 , the total volume of the market of agricultural machinery can reach 200 billion rubles, and by 2030, this figure can amount to 265 billion rubles. The structure of the equipment market for the agricultural sector is determined by the priorities of the development of its industries, so the largest share of the market volume will be combine harvesters with the share to be about $35 \%$ in the total volume, as well as tractors with the same indicator about $27 \%$.

It is expected that the volume of sales of combine harvesters over the last 6 years will increase by $25 \%$, and tractors by $20 \%$. (According to the forecast of the Ministry of Agriculture).

Thus, in the future, it is necessary to achieve the share of agricultural machinery in the domestic market of at least $80 \%$, while constantly increasing the share of export deliveries, bringing it to $50 \%$ of the value of shipments to the domestic market.

The process of creating favourable conditions for the development of the Russian producer in general, and, in particular, for the producers of agricultural machines plays an important role in the achievement of such indicators. Providing a competitive environment for the agricultural machinery, for the development of export of agricultural machinery, continuous development of innovation and research base for the development of this 
production will allow to develop competitive machinery for one of the basic sectors of the country - agricultural machinery.

Among the main objectives there is a providing of equal competitive conditions with foreign producers of agricultural machinery, creating favorable conditions for development of export of farm vehicles, stimulation of growth of investments into research and development and development of new types of competitive farm vehicles.

This process requires considerable attention to all spheres of the economy, from financial to direct State instruments, which help to accelerate the process of adapting the agricultural producer to the realities of recent years. Increasing investment, creating a favourable investment climate, innovative developments that promote the production of competitive agricultural machines, maintaining domestic demand at a stable level - all this will stimulate the production and supply of agricultural machinery and contribute to the increasing trend of domestic demand for it.

It is in these conditions that the problem of providing state support to the Russian agricultural mechanical engineer becomes particularly urgent.

The creation of an effective tool of such state support, the development of a competitive strategy of measures of state influence on this market is a systematic process to study both technical samples of agricultural machinery and assess their effective application. Several points should therefore be taken into account in addressing the issue of an adequate strategy to assist agricultural engineers:

- There is a need to develop a unified information and statistical approach to the quantitative and qualitative assessment of existing agricultural equipment;

- An adequate evaluation system of state support measures for agricultural engineering should be developed, taking into account its orientation not only to achieve economic efficiency of application of technical means, but also qualitative impact on sphere of social efficiency, taking into account changes both in wages of agricultural cluster employees and in working conditions, which can attract qualified labor reserve to this sphere [15].

\section{References}

1. Y. Greenwald, Ecological Economics 151, 1-9 (2018)

2. G.N. Ryazanova, IFAC-PapersOnLine 52, 225-230 (2019)

3. I.M. Peshkhoev, I.V. Avlasenko, O.V. Panfilova, Y.V. Podkolzin, O.G. Savelyeva, The Perspectives on the Use of New Information and Communication Technology (ICT) in the Modern Economy. ISC (2017). Advances in Intelligent Systems and Computing 726 (Springer, Cham, 2019)

4. I. Soldatova, Political Volatility. Economics World 3, 1-2 (2015)

5. V. Uzun, N. Shagaida, Z. Lerman, Russian agriculture: Growth and institutional challenges Land Use Policy 83, 475-487 (2019)

6. V. Glinskiy, L. Serga, M. Alekseev, N. Samotoy, E. Simonova, The Development of the Food Industry as a Condition for Improving Russia's National Security Procedia Manufacturing 21, 838-845 (2018)

7. F. Schierhorn, D. Müller, A.V. Prishchepov, M. Faramarzi, A. Balmann, Global Food Security 3, 133-141 (2014)

8. T.V. Zhukova, O.V. Panfilova, I.V. Avlasenko, L.M. Avlasenko, A.V. Belousova, International Conference Project "The future of the Global Financial System: Downfall of Harmony" ISC 2018: The Future of the Global Financial System: Downfall or Harmony, 774-782 (2018)

9. M. Svanidze, L. Götz, Global Food Security 21, 60-68 (2019) 
10. E. Nikolaeva, Procedia - Social and Behavioral Sciences 238, 364-373 (2018)

11. Z. Lerman, N. Shagaida, Land Use Policy 24, 14-23 (2007)

12. M. Svanidze, L. Götz, Global Food Security 21, 60-68 (2019)

13. M. Svanidze, L. Götz, Determinants of spatial market efficiency of grain markets in Russia Food Policy 89, 101769 (2019)

14. G. Salimova, A. Ableeva, G. Khabirov, Z. Zalilova, A. Hazieva, Journal of the Saudi Society of Agricultural Sciences (2020)

15. N. Stupak, Environmental Science \& Policy 68, 10-19 (2017) 